\title{
STRATEGI IMPLEMENTASI MODEL PENDIDIKAN KARAKTER DALAM PEMBELAJARAN AGAMA ISLAM DI FAKULTAS HUKUM UNIVERSITAS BRAWIJAYA
}

\author{
Nur Chanifah \\ Fakultas Hukum, Universitas Brawijaya \\ Jl. MT Haryono 169 Malang 65145 \\ E-mail: nur.chanifah@ub.ac.id
}

\begin{abstract}
ABSTRAK
Pendidikan tinggi telah memiliki payung hukum dalam pelaksanaan pendidikan Karakter. Sebagai upaya konkrit ke arah solusi, telah ditetapkan suatu Undang-Undang Republik Indonesia nomor 12 tahun 2012 tentang Pendidikan Tinggi. Untuk itu, Universitas Brawijaya, melalui Pusat Matakuliah Pengembangan Kepribadian (PMPK) telah merancang model pendidikan karakter. Masalahnya adalah bagaimana fakultas mengimplementasikan model tersebut. Untuk itu, kajian ini difokuskan pada implementasi model pendidikan karakter di Fakultas Hukum. Penelitian ini tergolong dalam studi kasus. Metode yang digunakan adalah observasi, wawancara, dan dokumentasi. Sedangkan teknik analisisnya berprinsip on going analysis dengan tahapan analisis selama pengumpulan data, reduksi data, penyajian data, dan pengambilan kesimpulan. Hasil penelitian menunjukkan bahwa model pendidikan karakter di Universitas Brawijaya terintegrasi dalam terintegrasi dengan Tri Dharma Perguruan Tinggi, yaitu kegiatan pendidikan yang meliputi kegiatan kurikuler, ko kurikuler, dan ekstra kurikuler, penelitian , dan pengabdian masyarakat. Karakter yang dikembangkan adalah karakter kreatif, entrepreneur, religius, dan nasionalis. Sedangkan strategi implementasinya di fakultas hukum diintegrasikan ke dalam beberapa kegiatan, yaitu kegiatan kurikuler, ko kurikuler, dan ekstra kurikuler. Kegiatan kurikuler mencakup pengembangan RPS, materi, metode, dan evaluasi pembelajaran. Untuk kegiatan ko kurikuler diimplementasikan dalam kegiatan bimbingan membaca al-Quran di Masjid Raden Patah, tutorial, pelatihan shalat khusyu' dan pelatihan perawatan jenazah. Sedangkan kegiatan ekstra kurikuler diintegrasikan dalam PKM, UKM FORSA, dan kajian di masjid Raden Patah.
\end{abstract}

Kata kunci: Strategi Implementasi, model pendidikan karakter, pembelajaran, pendidikan Agama Islam, Universitas Brawijaya

\section{PENDAHULUAN}

Pengembangan karakter menurut al-Ghazali harus diterapkan sejak usia dini. Meskipun demikian, pengembangan karakter di Perguruan Tinggi merupakan tahapan yang tidak kalah pentingnya dari pembentukan karakter di tingkat sekolah (Chanifah, Desain Pendidikan Karakter di Perguruan Tinggi Umum, 2015). Hal ini sesuai dengan hasil penelitiannya Ayi Suherman bahwa pendidikan karakter harus terus berlanjut sampai ke perguruan tinggi tentang pendidikan karakter di perguruan tinggi (Suherman, 2018), Wilhelm Von Humboldt, Cardinal John Henry Newman, and Jose Ortega Y Gasset tentang beberapa pemikiran tentang pendidikan karakter di perguruan tinggi (Wilhelm Von Humboldt, 2015). Penelitian-penelitian tersebut mempunyai kesimpulan yang sama bahwa pendidikan karakter di Perguruan Tinggi itu sangat penting, meskipun porsinya tidak sebanyak pendidikan karakter di tingkat dasar dan menengah. Oleh karena itu, perguruan tinggi harus merancang bagaimana strategi yang bisa diterapkan untuk mengimplementasikan pendidikan karakter.
Perguruan tinggi umum (PTU) telah memiliki payung hukum pelaksanaan pendidikan nilai di kalangan perguruan tinggi. Sebagai upaya konkrit ke arah solusi, telah ditetapkan suatu Undang-Undang Republik Indonesia nomor 12 tahun 2012 tentang Pendidikan Tinggi. Dalam Undang Undang tersebut secara eksplisit menyebutkan bahwa kurikulum nasional setiap perguruan tinggi wajib memuat mata kuliah Pancasila, kewarganegaraan, agama dan bahasa Indonesia. (Ridho, 2016) Di PTU, kelompok mata kuliah tersebut dikenal sebagai kelompok mata kuliah pengembangan kepribadian (MPK).

Akan tetapi, pengembangan karakter di perguruan tinggi tidak begitu banyak mendapat perhatian. Padahal, beberapa tahun terakhir ini, perguruan tinggi dikejutkan dengan beberapa penyimpangan yang dilakukan oleh mahasiswa maupun dosen. (Muhdar, 2013) Banyaknya fenomena menyontek(Sukmawati, 2016), kecanduan narkotika, (Nasir, 2013) hilangnya rasa malu, dan berkembangnya plagiarisme. Kasus yang hampir sama juga terjadi di Universitas Brawijaya. Dari observasi dan 
wawancara awal, ditemukan bahwa seluruh isi makalah mahasiswa hasil dari copy paste internet, pakaian mahasiswi yang tidak sopan, tidak menghormati dosen, tutur katanya yang tidak sopan, mengabaikan dosen. (Chanifah, akhlak mahasiswa, 2019)

Pendidikan mempunyai peran yang sangat signifikan dalam mengatasi problem tersebut. Hal ini bisa dirujuk dari Undang-undang Tahun 2013 Pasal 3 Nomor 20 tentang Sistem Pendidikan Nasional, bahwa hakikat pendidikan tidak hanya mengajar (transfer of knowledge) saja, tetapi lebih dari itu yaitu mendidik agar berakhlak. Hal senada juga diungkapkan oleh Wage dalam penelitiannya bahwa hakikat pendidikan agama Islam adalah transfer of value. (W Wage, 2016)

Sementara itu menurut Furqan, pengertian akhlak itu sama dengan karakter. Karakter merupakan kualitas mental atau kekuatan moral, akhlak, atau budi pekerti yang melekat pada diri seseorang sehingga mampu menjadi pendorong atau penggerak dalam melakukan sesuatu. (Hidayatullah, 2010) Dengan demikian, tujuan dari pendidikan harus mengarah pada pembentukan akhlak atau karakter. Karakter yang terbangun diharapkan akan mendorong setiap manusia untuk mengerjakan sesuatu sesuai dengan suara hatinya. Karena suara hati tidak akan mengarah pada hal yang negatif.

Lantas bagaimana cara yang bisa ditempuh untuk membangun karakter tersebut, tentu itu bukan persoalan yang mudah. Dalam hal ini, Lickona mengembangkan proses pengembangan karakter yang dia gagas, yaitu moral knowing, moral feeling, dan moral action. Pertama, mahasiswa mempelajari muatan moral (moral knowing), belajar mengetahui yang baik melalui melalui informasi pembuatan keputusan rasional. penalaran moral, pengambilan keputusan, dan kemampuan untuk mendapatkan pengetahuan-diri melalui pengamatan dan evaluasi perilaku semuanya penting dalam dimensi perkembangan karakter ini. Kedua, domain afektif yang mencakup perasaan, simpati, kepedulian, dan cinta pada orang lain (moral feeling). (Mulyasa, 2012)

Lebih lanjut pada tahun 1992 Lickona menambahkan elemen ini dengan hati nurani, cinta, empati, dan kerendahan hati sebagai aspek penting darinya. (Hidayatullah, 2010) Ada atau tidak adanya unsur perasaan dalam perkembangan karakter sangat menentukan apakah mahasiswa melakukan yang benar atau tidak. Oleh karena itu, domain afektif oleh Lickona dianggap sebagai jembatan penting dalam tindakan moral. Ketiga, tindakan tergantung pada kemauan, kompetensi, dan kebiasaan seseorang (moral action). Kehendak di sini berarti bahwa mahasiswa harus menghendaki cara mereka untuk mengatasi kepentingan diri sendiri, dan setiap kebanggaan atau kecemasan yang mereka miliki untuk melakukan apa yang mereka tahu adalah tindakan yang benar. Lebih lanjut, mahasiswa harus mengembangkan kompetensi untuk melakukan "yang baik" yang melibatkan ketrampilan tertentu dan mereka harus bebas memilih untuk mengulangi tindakan yang baik ini sebagai bentuk kebiasaan. (Mulyasa, 2012)

Jika dipahami lebih lanjut, sebenarnya karakter itu bergerak dari kesadaran (awareness), pemahaman (understanding), kepedulian (concern), dan komitmen (commitment), menuju tindakan (doing atau acting). Untuk itu, perlu adanya kerjasama dan komitmen dari seluruh unsur yang ada di perguruan tinggi. Dalam implementasinya, membangun karakter sebaiknya diajarkan melalui tindakan, bukan hanya teoritis. Moral understanding sebagai aspek pertama yang harus diperhatikan dalam pendidikan karakter memiliki enam unsur, yaitu kesadaran moral, (moral awarness), pengetahuan tentang nilai-nilai moral (knowing about moral values), penentuan sudut pandang (perspective taking), logika moral (moral reasoning), keberanian mengambil keputusan (decision making), dan pengenalan diri (self knowledge). Unsur tersebut merupakan komponen-komponen yang harus ditekankan dalam pendidikan karakter, serta diajarkan kepada peserta didik dan diintegrasikan dalam seluruh pembelajaran secara kaffah. (Narvaez, 2014)

Moral loving/moral feeling merupakan penguatan aspek emosi peserta didik untuk menjadi manusia berkarakter. Penguatan ini berkaitan dengan bentuk-bentuk sikap yang harus dirasakan oleh peserta didik, yaitu kesadaran akan jati diri, percaya diri (self-discipline), kepekaan terhadap penderitaan orang lain (emphaty), cinta kebenaran (loving the good), pengendalian diri (selfcontrol), dan kerendahan hati (humility). Jika kedua aspek di atas terwujud, maka moral acting sebagai outcome akan dengan mudah dilakukan. (Mulyasa, 2012)

Akan tetapi, dalam realitasnya, seringkali terjadi keterputusan di antara unsur-unsur tersebut, seringkali hanya sekedar moral knowing kemudian dituntut untuk bisa langsung moral action, tanpa moral feeling, sehingga wajar kalau karakter itu tidak terbangun. Hal ini bisa dilihat dari kasus-kasus yang terjadi dalam pendidikan kita. Beberapa tahun terakhir ini, dikejutkan dengan beberapa penyimpangan yang dilakukan oleh mahasiswa maupun dosen. Banyaknya fenomena menyontek, hilangnya rasa malu, dan berkembangnya plagiarisme (plagiat). Kondisi inilah yang menjadikan pembangunan karakter mahasiswa mendesak dilaksanakan di perguruan tinggi. (Luneto, 2017)

Di antara penelitian yang menjelaskan tentang pendidikan karakter di perguraun tinggi adalah penelitian walid di UIN Malang. Hasilnya adalah model pendidikan karakternya berorientasi pada karakter ulul albab yang diintegrasikan pada pesantren mahasiswa, kegiatan intrakurikuler, kokurikuler, dan ekstrakurikuler. (Walid, 2011)Tentu model tersebut kurang sesuai untuk perguruan 
tinggi umum, mengingat background mahasiswanya beragam.

Selain itu, penelitian Sri Winarni juga menjelaskan tentang strategi implementasi pendidikan karakter dalam kegiatan perkuliahan (Winarni, 2013), Wanda Chrisiana dan Rosa Susanti tentang implementasi pendidikan karakter pada mahasiswa (Chrisiana, 2019). Akan tetapi, semua penelitian tersebut masih bersifat umum, yaitu untuk semua perkuliahan, tidak fokus pada pembelajaran Agama Islam (Susanti, 2013). Sementara itu penelitiannya Nur chanifah hanya menjelaskan bagaimana pengembangan kurikulum yang berbasis karakter, tidak menejelaskan implementasi pendidikan karakter. (Chanifah, Pengembangan Kurikulum Pendidikan Agama Islam Berbasis Karakter, 2015).

Berdasarkan penelitian terdahulu di atas, maka kajian tentang strategi implementasi pendidikan karakter dalam pembelajaran PAI di Fakultas Hukum Universitas Brawijaya belum ada. Dalam hal ini, Universitas Brawijaya, melalui Pusat Matakuliah Pengembangan Kepribadian (PMPK) telah merancang model pendidikan karakter. Model tersebut dirancang oleh bidang pengkajian dan pembinaan karakter bersama TIM yang sudah dibentuk.

Dalam implementasinya, model tersebut lebih fokus pada empat matakuliah pengembangan kepribadian di mana matakuliah Pendidikan Agama Islam (PAI) masuk di dalamnya. Saat ini, para dosen masih belum bisa mengimplementasikan model tersebut secara optimal, mengingat jumlah sks yang diberikan hanya 2 sks, sementara berorientasi untuk mengembangkan karakter mahasiswa. Untuk itu, penelitian ini penting dilakukan untuk mengetahui bagaimana strategi implementasi model pendidikan karakter dalam pembelajaran PAI di Universitas Brawijaya. Dengan adanya penelitian ini diharapkan dapat memberikan pedoman bagi para dosen untuk mengimplementasikan model pendidikan karakter.

\section{RUANG LINGKUP}

Adapun ruang lingkup penelitian ini adalah sebagai berikut:

1) Model pendidikan karakter di Universitas Brawijaya

2) Strategi implementasi pendidikan karakter dalam pembelajaran Pendidikan Agama Islam (PAI) di Fakultas Hukum Universitas Brawijaya

\section{BAHAN DAN METODE}

Penelitian ini termasuk dalam studi kasus dengan lokasi penelitian di fakultas hukum Universitas Brawijaya. Untuk pemilihan informan menggunakan teknik purposive sampling dengan memilih key informant yaitu koordinator dosen matakuliah Pendidikan Agama Islam. Pemilihan informan selanjutnya menggunakan snowballing yaitu dengan memilih para dosen dan mahasiswa berdasarkan informasi dari key informant. Untuk tahapan penelitian ini diawali dengan melakukan observasi awal, wawancara mendalam, observasi partisipan, dokumentasi, reduksi data, penyajian data, dan pengambilan kesimpulan.

1. Observasi awal. Penelitian ini diawali dengan kegiatan observasi untuk mendapatkan data awal tentang bagaimana implementasi pendidikan karakter di Universitas Brawijaya. Dalam tahap ini, telah didapatkan data yang berkaitan dengan prilaku mahasiswa di Universitas Brawijaya, pelaksanaan pembelajaraan pendidikan Agama Islam (PAI), dan suasana kegiatan pembelajaran PAI di dalam kelas maupun di luar kelas.

2. Wawancara Mendalam. Setalah data didaptkan dari observasi, maka tahapan selanjutnya adalah melakukan wawancara mendalam kepada koordinator dosen matakuliah PAI untuk mendapatkan info terkait siapa saja dosen yang bisa diwawancarai tentang strategi implementasi pendidikan karakter. Setalah itu, wawancara dilakukan kepada para dosen PAI dan mahasiswa yang mengikuti matakuliah PAI. Data yang didapatkan adalah terkait dengan strategi yang diterapkan oleh dosen dalam mengimplementasikan pendidikan karakter. Sedangkan wawancara dengan mahasiswa menghasilkan data terkait dengan respon mahasiswa dalam mengikuti pembelajaran PAI dan dampak pembelajaran PAI dalam pengembangan karakter.

3. Observasi partisipan. Setelah melakukan wawwancara, peneliti melakukan observasi partisapan dengan mengikuti langsung kegiatan pembelajaran PAI di kelas untuk mendapatkan data terkait dengan kegiatan pembelajaran dan respon mahasiswa dalam kegiatan tersebut.

4. Dokumentasi. Setelah data dari wawancara didapatkan, maka tahapan selanjutnya adalah mencari dokumen terkait dengan strategi implementasi pendidikan karakter dalam pembelajaran PAI. Data yang didapatkan berupa perangkat pembelajaran (RPS dan sistem evaluasi), foto kegiatan, dan makalah atau karya ilmiah dosen terkait dengan implementasi pendidikan karakter.

Setelah data terkumpul, maka tahapan selanjutnya adalah reduksi data. Dalam tahap ini, peneliti menyeleksi data mana yang sesuai atau penting dalam penelitian mana yang tidak. Data yang tidak sesuai akan dibuang. Setelah data diseleksi, maka tahap selanjutnya adalah menyajikan dan menyimpulkan sesuai dengan rumusan masalah penelitian.

\section{PEMBAHASAN}

Dalam konteks mikro, pendidikan karakter berpusat pada satuan pendidikan secara holistic. Satuan pendidikan merupakan sector utama yang secara optimal 
memanfaatkan dan memberdayakan semua lingkungan belajar yang ada untuk menginisiasi, memperbaiki, menguatkan, dan menyempurnakan secara terus menerus proses pendidikan karakter di satuan pendidikan. Pendidikanlah yang akan melakukan upaya sungguhsungguh dan senantiasa menjadi garda depan dalam upaya pembentukan karakter manusia Indonesia yang sesungguhnya.

Dalam implementasinya, semua komponen harus dilibatkan secara optimal, komponen penyelenggara dan tenaga kependidikan seperti pimpinan Rektor, Dekan, Ketua Sekolah Tinggi, Ketua Jurusan, dosen dan karyawan, kurikulum, proses pembelajaran dan penilaian, kualitas hubungan, penanganan atau pengelolaan mata kuliah, pelaksanaan aktivitas atau kegiatan baik intra maupun ekstra kampus, pemberdayaan sarana prasarana, pembiayaan, dan ethos kerja seluruh civitas akademika dan lingkungan Perguruan Tinggi secara bersinergis harus saling mendukung terselenggaranya pendidikan karakter dengan baik. Intinya, semua faktor yang dapat mempengaruhi hasil pendidikan karakter yang diinginkan harus terlibat dengan baik.

Implementasi tersebut didasarkan pada lima pilar utama, yaitu (1) Tri Darma Perguruan Tinggi. Pendidikan karakter bisa diintegrasikan ke dalam kegiatan pendidikan, penelitian dan pengabdian kepada masyarakat yang berkarakter. Jika terjadi, akan ada dalam pembiasaan kehidupan keseharian di kampus yang menjadi budaya kampus. (2) Budaya Perguruan Tinggi (kampus) atau budaya organisasi. Mahasiswa dituntut untuk dapat membiasakan diri dalam kehidupan keseharian di lingkungan kampus. (3) Kegiatan kemahasiswaan. Pendidikan karakter dapat diciptakan melalui integrasi ke dalam kegiatan kemahasiswaan, antara lain pramuka, olahraga, rohis, karya tulis, seni, workshop, dan acara yang melibatkan mahasiswa dalam sistem kepanitiaannya. (4) Kegiatan keseharian. Pendidikan karakter dapat dimunculkan dengan penerapan pembiasaan kehidupan keseharian di kelas, asrama, dan masyarakat. (5) Budaya akademik. Nilai pendidikan karakter secara persfektif terbentuk dengan adanya totalitas budaya akademik.

Uraian di atas memberikan gambaran, bahwa pendidikan karakter sebenarnya bisa dengan mudah diterapkan pada mahasiswa, karena setiap unit yang ada diperguruan tinggi mampu menampung pemberdayaan pendidikan karakter. Oleh karena itu semua pihak yang terlibat, tidak hanya dosen sebagai pengampu mata kuliah, namun juga semua civitas akademika, orang tua, masyarakat, dan mahasiswa yang bersangkutan harus bisa bekerja sama dalam rangka penerapan pendidikan karakter.

Adapun penerapannya harus mempunyai strategi guna mencapai hasil yang diinginkan, ada beberapa strategi yang bisa digunakan dalam penerapan pendidikan karakter (Winarni, 2013), yaitu pertama melalui pembelajaran . Strategi penerapan pendidikan karakter melalui pembelajaran bisa dilakukan melalui 2 cara, yaitu penguatan matakuliah Pendidikan Agama, Pendidikan Pancasila, Pendidikan Kewarganegaraan, Ilmu Alamiah Dasar, dan Ilmu Sosial Budaya Dasar, serta pengintegrasian pendidikan karakter kesetiap mata kuliah bidang keilmuan, teknologi, dan seni.

Kedua, melalui ekstrakulikuler Strategi ini dengan cara menerapkan proses pendidikan karakter melalui kegiatan yang melibatkan mahasiswa di dalamnya, yaitu 1) lembaga kemahasiswaan, seperti Badan Eksekutif Mahasiswa, Keluarga Mahasiswa, Himpunan Mahasiswa, dan Kelompok Belajar, 2) melalui unit kegiatan mahasiswa, seperti pramuka, Menwa, olahraga, pecinta alam, dan lainlain.

Ketiga, melalui pengembangan budaya perguruan tinggi Budaya perguruan tinggi dibagi menjadi tiga unit, 1) budaya akademik, penerapan pendidikan karakter bisa melalui pengembangan ilmu pengetahuan dan teknologi, 2) budaya humanis, disini hubungan harmonis sesame warga perguruan tinggi serta warga perguruan tinggi dengan masyarakat berdasarkan cinta kasih, kepedulian, dan gotong royong diharap mampu mengembangkan pendidikan karakter, 3) budaya religius, pendidikan karakter dapat diterapkan melalui iman dan taqwa kepada Tuhan YME, menjalankan syariat agama, saling menghormati antar sesame pemeluk agama dan antara pemeluk agama lainnya.

Uraian strategi di atas diharapkan mampu melahirkan insan akademis Indonesia yang berkarakter, jujur, cerdas, peduli, dan tangguh. Selain itu perguruan tinggi juga memiliki pilihan dalam mengajarkan pembentukan karakter karena dapat mengintegrasikan dan mengajarkan secara alami dengan mata kuliah pada semua kelas oleh semua pendidik. Walaupun begitu, hal ini tentu saja menimbulkan konsekuensi cara pengajaran yang berbeda dan cara pemberian nilai yang berbeda, dosen tidak hanya mengevaluasi penguasaan teori atau kemampuan kognitif mahasiswa, namun juga mengevaluasi implementasi karakter atau nilai-nilai luhur. Selain itu dosen semua mata kuliah hendaknya menjadi figur yang mempraktekkan pembentukkan karakter ini dalam semua aktivitas di kelas maupun di luar kelas. Apabila hal ini bisa dilakukan, maka dapat mempermudah pembentukan karakter pada setiap individu mahasiswa, sehingga mereka nantinya bisa menjadi pribadi dewasa yang matang dan bertanggung jawab. (Winarni, 2013)

Pendidikan karakter dalam kegiatan pembelajaran di kelas dilaksanakan dengan menggunakan pendekatan terintegrasi dalam semua matakuliah, khususnya matakuliah pengembangan kepribadian (MPK). Dalam kegiatan tersebut, karakter dikembangkan sebagai dampak pembelajaran dan dampak pengiring. Sedangkan bagi mata mata kuliah lain cukup melahirkan dampak pengiring. Nilai tidak diajarkan tapi dikembangkan (value is neither 
caught nor taught, it is learned) mengandung makna bahwa materi nilai-nilai dan karakter bangsa bukanlah bahan ajar biasa. Tidak semata-mata dapat ditangkap sendiri atau diajarkan, tetapi lebih jauh diinternalisasi melalui proses belajar. Artinya, nilai-nilai tersebut tidak dijadikan pokok bahasan yang dikemukakan seperti halnya ketika mengajarkan suatu konsep, teori, prosedur, atau pun fakta seperti dalam mata pelajaran tertentu.

Selain itu, lingkungan satuan pendidikan perlu dikondisikan agar lingkungan fisik dan sosio-kultural satuan pendidikan memengkinkan mahasiswa bersama dengan warga satuan pendidikan lainnya terbiasa membangun kegiatan keseharian di satuan pendidikan yang mencerminkan perwujudan karakter yang dituju. Pola ini ditempuh dengan melakukan pembiasaan pembudayaan aspek-aspek karakter dalam kehidupan keseharian di kampus dengan dosen sebagai teladan. Dalam kegiatan ko kurikuler atau ekstra kurikuler perlu dikembangkan proses pembiasaan dan penguatan dalam rangka pengembangan karakter. Kegiatan ekstra kurikuler dapat diselenggarakan melalui kegiatan olahraga dan seni, pramuka, Menwa, Rohis, dan lain-lain. Di lingkungan keluaraga dan maasyarakat diupayakan agar terjadi proses penguatan dari orang tua/wali serta tokoh-tokoh masysrakat terhadap perilaku berkarakter mulia yang dikembangkan di satuan pendidikan sehingga menjadi kegiatan keseharian di rumah dan di lingkungan masyarakat masing-masing. (Mustafa, 2013)

\subsection{Model Pendidikan Karakter di Universitas Brawijaya}

Model Pendidikan karakter di Universitas terintegrasi (tidak berdiri sendiri sebagai matakuliah) dengan seluruh aktivitas Tri Dharma Perguruan Tinggi yang meliputi: Pertama, kegiatan ini mencakup kegiatan (1) Intrakurikuler yang meliputi Penyusunan silabus dan RPS, Materi pembelajaran (penekanan MPK), Metode pembelajaran, Evaluasi pembelajaran. (2) Kegiatan kokurikuler yang mencakup Kuliah Tutorial, Pelatihan perawatan jenazah, Pelatihan shalat khusyu', Sekolah kebangsaan, Diskusi Bulanan Guru Bangsa, Pembinaan Bahasa. (3) Kegiatan Ekstra kurikuler yang mencakup bidang penalaran dan keilmuan yang meliputi Pekan Ilmiah Nasional (PIMNAS), Program Kreatifitas Mahasiswa (PKM), Mahasiswa Berprestasi (Mawapres); Bakat, minat dan kemampuan meliputi Pramuka dan Seni Religi; Kesejahteraan meliputi Beasiswa, asrama, MTQ, kantin, paduan suara, koperasi; Kepedulian sosial yang meliputi pengembangan desa binaan, dialog kemahasiswaan, baksos.

Kedua, kegiatan penelitian yang berupa lomba karya tulis ilmiah program kreatifitas mahasiswa, penulisan skripsi, dan penelitian kolaborasi dengan Dosen. Ketiga, pengabdian masyarakat yang mencakup kegiatan program pengabdian masyarakat atau kuliah kerja nyata $(\mathrm{KKN})$, dan Magang.

Sedangkan nilai yang dikembangkan dalam model pengembangan karakter di Universitas Brawijaya adalah: pertama, karakter kreatif dengan indikator adanya kemampuan untuk menginisiasi sesuatu yang baru, kemauan untuk menghasilkan sebuah karya, kemampuan untuk memperbaiki sebuah karya. Kedua, karakter entrepreneur dengan indikator memiliki jiwa kewirausahaan (inovatif, kompetitif, mandiri, pelopor/perintis). Karakter ini mencakup dua dimenasi yaitu (1) dimensi prilaku yang mencakup reaksi terhadap faktor perubahan, evaluasi sumber daya, tindakan nyata dalam merespon peluang, merubah realitas menjadi kemanfaatan . (2) dimensi sikap yang terkait dengan mencari tantangan dan peluang, menerima dan mengelola resiko, perubahan yang kreatif, konsisten dalam tindakan.

Ketiga, karakter religius yang mencerminkan keberimanan terhadap Tuhan yang Maha Esa yang diwujudkan dalam perilaku melaksanakan ajaran agama dan kepercayaan yang dianut, menghargai perbedaan agama, menjunjung tinggi sikap toleran terhadap pelaksanaan ibadah agama dan kepercayaan lain, hidup rukun dan damai dengan pemeluk agama lain. Implementasi nilai karakter religius ini ditunjukkan dalam sikap cinta damai, toleransi, menghargai perbedaan agama dan kepercayaan, teguh pendirian, percaya diri, kerja sama antar pemeluk agama dan kepercayaan, anti perundungan dan kekerasan, persahabatan, ketulusan, tidak memaksakan kehendak, mencintai lingkungan, melindungi yang kecil dan tersisih.

Keempat, karakter nasionalis yang mencakup cara berpikir, bersikap, dan berbuat yang menunjukkan kesetiaan, kepedulian, dan penghargaan yang tinggi terhadap bahasa, lingkungan fisik, sosial, budaya, ekonomi, dan politik bangsa, menempatkan kepentingan bangsa dan negara di atas kepentingan diri dan kelompoknya. Sikap nasionalis ditunjukkan melalui sikap apresiasi budaya bangsa sendiri, menjaga kekayaan budaya bangsa, rela berkorban, unggul, dan berprestasi, cinta tanah air, menjaga lingkungan, taat hukum, disiplin, menghormati keragaman budaya, suku, dan agama.

\subsection{Strategi Implementasi Pendidikan Karakter di Fakultas Hukum Universitas Brawijaya}

Pendidikan karakter dapat diimplementasikan melalui tiga kegiatan, yaitu kegiatan intrakurikuler, kkokurikuler, dan ekstrakurikuler. Kegiatan intrakuriluler merupakan kegiatan utama yang dilakukan dengan menggunakan alokasi waktu yang telah ditentukan dalam struktur kurikulum di Perguruan Tinggi. Kegiatan ini dilaksanakan oleh Dosen dan mahasiswa secara rutin dan terjadwal dalam kegiatan pembelajaran setiap hari efektif pada kalender pendidikan. Kegiatan kurikuler ini diberikan 
kepada seluruh mahasiswa untuk mencapai tujuan minimal setiap matakuliah yang tergolong inti maupun penunjang di Perguruan Tinggi.

Kegiatan intrakurikuler meliputi: pertama, kegiatan pengembangan RPS. Dosen PAI menyusun RPS yang disesuaikan dengan disiplin ilmu hukum. Hal ini dikarenakan kurikulum yang diberikan oleh Kemenristek DIKTI, yakni pada SK No 43 tahun 2006 menyangkut seluruh disiplin ilmu (belum fokus pada disiplin ilmu tertentu). Oleh karena ini, pengembangkan RPS ini dilakukan untuk lebih memfokuskan pada pengembangan karakter mahasiswa berdasarkan latar belakang disiplin ilmu, yaitu ilmu hukum.

Pengembangan RPS dalam mengembangkan karakter ini mencakup beberapa aspek, di anataranya adalah: (1) Capaian Pembelajaran yang mencakup aspek sikap, pengetahuan, ketrampilan umum dan ketrampilan khusus. (2) Rencana Pembelajaran yang mencakup capaian pembelajaran tiap tahap, bahan kajian, metode pembelajaran, dan pengalaman belajar mahasiswa. (3) Referensi yang mencakup referensi utama maupun referensi pelengkap. (4) Sistem penilaian yang mencakup komponen penilaian, bentuk penilaian, criteria penilaian, indikator penilaian, dan bobot penilaian.

Kedua, pengembangan materi pembelajaran yang didasarkan pada struktur kurikulum yang diberikan oleh Kemenristek Dikti. Materi pembelajaran yang diberikan kepada semua fakultas sama. Tentu kurikulum tersebut dapat menyulitkan mahasiswa, karena mempunyai background disiplin kelimuan yang berbeda. Untuk itu, dosen Pendidikan Agama Islam di Fakultas hukum menambahkan materi pembelajaran yang yang berkaitan dengan disiplin ilmu hukum. Untuk mengakomodir kurikulum Kemenristek Dikti, dosen PAI membagi materi pembahsannya yang sebelum UTS dengan setelah UTS. Materi pembelajaran sebelum UTS, masih bersifat umum (sesuai dengan struktur kurikulum Dikti). Sementara itu, materi setelah UTS sudah menyesuaikan dan fokus dengan disiplin ilmu hukum. Kendala yang dihadapi dosen adalah belum tersedia bahan ajar yang seuai dengan kurikulum tersebut. Oleh karena itu, dosen PAI perlu menyusun buku ajar baru yang sesuai dengan RPS Fakultas hukum.

Ketiga, pengembangan metode pembelajaran yang diterapkan oleh dosen dalam mengembangkan karakter mahasiswa bervariasi. Di antara metode yang dipakai adalah:

1. Diskusi : diskusi adalah metode yang paling banyak diterapkan oleh dosen PAI karena metode ini cukup efektif untuk mengembangkan karakter mahasiswa. Ada beberapa nilai karakter yang dikembangkan dengan metode ini, di antaranya adalah karakter kreatif (mempunyai gagasan atau ide baru), entrepreneur (memecahkan masalah, berani menerima resiko, inovatif, kompetitif), dan nasionalis (menghargai perbedaan pendapat, menerima kritik dan saran, terbuka).

2. Tugas: metode ini biasanya diterapkan oleh dosen kepada mahasiswa untuk memenuhi tugas terstruktur 1 maupun 2. Biasanya dosen memberikan tugas untuk membuat paper terkait dengan materi yang diajarkan atau menganalisis beberapa jurnal ilmiah. Metode ini bisa digunakan untuk mengembangkan karakter kreatif (mempunyai idea atau gagasan baru), entrepreneur (memecahkan masalah, mandiri, inovatif, kompetitif), religius (jujur, disiplin), dan nasionalis (tanggung jawab, menghargai perbedaan).

3. Observasi: metode ini diterapkan oleh dosen agar mahasiswa mempunyai pengalaman langsung terkait dengan materi yang dipelajari. Mahasiswa ditugaskan untuk melakukan observasi di tempat-tempat yang relevan dengan materi yang dikaji seperti di Pemerintah daerah, kantor DPRD, partai politik, dan lain lain. Dengan metode observasi tersebut, maka ada beberapa nilai karakter yang bisa dikembangkan, yaitu karakter kreatif (mengimplementasikan ide atau gagasan baru), entrepreneur (mandiri, inovatif, kompetetif, berani mengambil resiko), religius (jujur, disiplin), nasionalis (tanggung jawab, menerima perbedaan, menghargai orang lain).

4. Problem solving: metode ini diterapkan oleh dosen kepada mahasiswa untuk menyelesaikan persoalanpersoalan yang terkaiat dengan materi yang dibahas, seperti kasus toleransi umat beragama dan korupsi. Mahasiswa diminta untuk memaparkan kasus yang terkait dengan materi dan memberikan solusi untuk penyelesaiannya. Ada beberapa karakter yang bisa dikembangkan dalam metode ini, yaitu kreatif (mempunyai idea atau gagasana baru), entrepreneur (memecahkan masalah, mandiri, inovatif), religius (jujur, disiplin), dan nasionalis (tanggung jawab, menerima perbedaan pendapat).

Keempat, pengembangan sistem evaluasi yang diterapkan untuk mengembangkan karakter mahasiswa adalah observasi dengan check list. Ada beberapa pernyataan atau pertanyaan yang dibuat untuk mengetahui bagaimana kualitas pembelajaran. Semua pernyataan atau pertanyaan dituangkan dalam kolom dan diberi skala penilaian.

Semnatara itu, strategi implementasi pendidikan karakter yang kedua adalah diintegrasikan dalam kegiatan kokurikuler. Kegiatan kokurikuler adalah kegiatan yang menunjang kegiatan intrakurikuler. Kegiatan tersebut diimplemtasikan dalam beberapa kegiatan, yaitu: pertama, kegiatan bimbingan membaca al-Quran yang dilaksanakan atas bekerjasama dosen Pendidikan Agama Islam dengan takmir masjid Raden Patah. Kegiatan ini dilaksanakan setiap hari dengan beberapa shift. Mahasiswa dapat memilih salah satu jam yang mereka tidak bersamaan 
dengan jam kuliah. Untuk mendukung kegiatan ini masjid Raden Patah memberdayakan mahasiswa yang mempunyai kemampuan membaca al-Quran dengan baik untuk menjadi tutor.

Untuk mengikuti kegiatan tersebut, mahasiswa harus mengikuti pretest terlebih dahulu untuk mengetahui kemampuan membaca al-Quran mahasiswa. Dalam hal ini, mahasiswa akan dikelompokkan menjadi tiga tingkatan, yaitu tingkat pemula, tingkat menengah, dan tingkat lanjutan. Setelah mereka mengikuti kegiatan tersebut dengan minimal 10 kali pertemuan, mereka akan mendapatkan sertifikat dari takmir masjid. Karakter yang bisa dikembangkan dalam kegiatan ini adalah karakter religius.

Kedua, kegiatan tutorial yang dilaksanakan atas kerjasama dosen Pendidikan Agama Islam dengan Pusat Pembinaan Agama (PPA). Kegiatan ini dilaksanakan sekali setiap semester. Materi yang disampaikan dalam kegiatan tutorial ini adalah Islam dan disiplin ilmu, mengingat background keilmuan mahasiswa beragam. Dalam implementasinya, beberapa fakultas yang serumpun (bidang kajian) akan ditempatkan dalam satu tempat. Untuk fakultas hukum pelaksanaannya digabung dengan fakultas ilmu sosial dan politik. Kegiatan dimaksudkan agar tidak terjadi dikotomi antara Islam dengan disiplin ilmu mahasiswa. Karakter yang bisa dikembangkan dalam kegiatan ini adalah karakter kreatif, religius, dan nasionalis.

Ketiga, pelatihan Shalat Khusyu' yang diselenggarakan atas kerjasama dosen PAI dengan Pusat Pembinaan Agama (PPA). Kegiatan ini dilaksanakan sekali setiap semester. Tujuannya adalah untuk mengembangkan karakter religius mahasiswa. Dalam kegiatan ini, PPA mengndang Tim Shalat khusyu' dari Shalat Center atau dari Tim Ust. Abu Sangkan.

Keempat, pelatihan perawatan jenazah yang diselenggarakan atas kerja sama dosen PAI dengan PPA sekali dalam setiap semester. Dalam kegiatan ini mahasiswa akan praktek langsung bagaimana merawat jenazah mulai dari memandikan, mengkafani, dan menshalati. Dari kegiatan ini bisa dikembangkan karakter religius mahasiswa.

Sedangkan strategi implementasi pendidikan karakter yang ketiga adalah diintegrasikan dalam kegiatan kkstra kurikuler. Kegiatan tersebut meliputi: pertama, program kreatifitas mahasiswa (PKM) yang diselenggarakan oleh fakultas hukum. Berdasarkan hasil wawancara dengan mahasiswa fakultas hukum, hanya sebagian kecil yang mengikuti kegiatan PKM ini. Akan tetapi, mereka mengaku bahwa kegiatan PKM ini berdampak pada pengembangan karakter mereka. Kegiatan ini dapat mengembangkan karakter kreatif, entrepreneur, religius, dan nasionalis.
Kedua, forum studi agama Islam (FORSA) yang merupakan UKM religi di Fakultas hukum yang menyelenggarakan kegiatan keagamaan Islam di Universitas Brawijaya. Berdasarkan hasil wawancara dengan mahasiswa fakultas hukum, hanya sebagian kecil mahasiswa yang mengikuti kegiatan ini. Akan tetapi meraka juga mengaku bahwa dengan bergabung di UKM FORSA, karakter mereka terbentuk. Di antara karakter yang bisa dikembangkan dalam kegiatan ini adalah karakter kreatif, entrepreneur, religius, dan nasionalis.

Ketiga, kegiatan yang diselenggarakan di masjid Raden Patah Universitas Brawijaya. Selain kegiatan yang diselenggarakan oleh fakultas, mahasiswa juga mengikuti kegiatan yang diselenggarakan oleh Takmir Masjid Raden Patah. Dalam hal ini, dosen mewajibkan mahasiswa untuk mengikuti kajian di MRP sebagai kuliah tambahan yang diselenggarakan oleh dosen di kelas. Ada beberapa karakter yang bisa dikembangkan dalam kegiatan ini, yaitu karakter religius dan nasionalis.

\section{KESIMPULAN}

Model pendidikan karakter di Universitas Brawijaya terintegrasi dengan Tri Dharma Perguruan Tinggi, yaitu kegiatan pendidikan yang meliputi kegiatan kurikuler, ko kurikuler, dan ekstra kurikuler, penelitian , dan pengabdian masyarakat. Karakter yang dikembangkan adalah karakter kreatif, entrepreneur, religius, dan nasionalis. Sistem evaluasinya mencakup capaian kegiatan Tri Dharma Perguruan Tinggi.

Sedangkan strategi implementasi pendidikan karakter dalam pembelajaran PAI di fakultas hukum diintegrasikan ke dalam beberapa kegiatan, yaitu kegiatan kurikuler, ko kurikuler, dan ekstra kurikuler. Kegiatan kurikuler mencakup pengembangan RPS, materi, metode, dan evaluasi pembelajaran. Untuk kegiatan ko kurikuler diimplementasikan dalam kegiatan bimbingan membaca al-Quran di Masjid Raden Patah, tutorial, pelatihan shalat khusyu' dan pelatihan perawatan jenazah. Sedangkan kegiatan ekstra kurikuler diintegrasikan dalam program kreativitas mahasiswaa, UKM FORSA, dan kajian di masjid Raden Patah.

\section{SARAN}

Fakultas Hukum perlu merekonstruksi kurikulum, terutama berkaitan dengan pembelajaran PAI. Hal ini dikarenakan beban sks matakuliah PAI di fakultas hukum masih 2 sks. Sementara pendidikan agama Islam mempunyai peran dalam mengembangkan karakter mahasiswa. Untuk itu, perlu ada penambahan sks matakuliah PAI sehingga peran PAI dalam mengembangkan karakter mahasiswa bisa lebih optimal. 


\section{DAFTAR PUSTAKA}

Chanifah, N. 2019. akhlak mahasiswa. Malang: Universitas Brawijaya.

Chanifah, N. 2015. Desain Pendidikan Karakter di Perguruan Tinggi Umum. Seminar nasional Riset Inovatif III. Bali: Undiksha.

Chanifah, N. 2015. Pengembangan Kurikulum Pendidikan Agama Islam Berbasis Karakter. Urwatul Wutsqa .

Chrisiana, W. 2019. puslit.petra.ac.id. Retrieved juni 2017, from puslit.petra.ac.id: http://puslit.petra.ac.id/journals/industrial

Hidayatullah, F. 2010. Pendidikan Karakter: Membangun Peradaban Bangsa. Surakarta: UNS Press.

Luneto, B. 2017. pendidikan karakter berbasis IQ, EQ, dan $S Q$. gorontalo: http://journal.iaingorontalo.ac.id/index.php/ir.

Muhdar, H. 2013. Pendidikan Karakter menuju SDM Paripurna. al-Ulum, 103-128.

Mulyasa. 2012. Manajemen Pendidikan Karakter. Jakarta: Bumi Aksara.

Mustafa, A. 2013. Kebijakan Nasional Pembangunan Karakter bangsa tahun 2010-2025. Bali: Kemenristek Dikti.

Narvaez, L. P. 2014. Handbook of Moral and Character education. Bandung: Nusa Media.

Nasir. 2013. Pengembangan Pendidikan karakter berbasis budaya lokal di SMP Negeri 2 Kendari. Surakarta: Universitas Muhammadiyah Surakarta.

Ridho. 2016. Implementasi Pembelajaran Pendidikan Agama Islam di Perguruan Tinggi Umum (Studi Evaluatif di STKIP Sungai Penuh). Tarbawi: Jurnal Ilmu Pendidikan .

Suherman, A. 2018. The Implementation Of Character Education Values In Integrated Physical Education Subject In Elementary School. SHS Web of Conferences $\quad 42, \quad 00045$. https://doi.org/10.1051/shsconf/20184200045 GCTALE 2017.

Susanti, R. 2013. Jurnal al-Ta'lim , Penerapan Pendidikan Karakter di kalangan mahasiswa.

W Wage, A. S. 2016. Pemberdayaan Pendidikan Agama Islam di Sekolah dan Perguruan Tinggi Umum. Islamadina: Jurnal Pemikiran Islam .

Walid, M. 2011. MODEL PENDIDIKAN KARAKTER DI PERGURUAN TINGGI AGAMA ISLAM (Studi tentang Pendidikan Karakter Berbasis Ulul albab di Universitas Islam Negeri Maulana Malik Ibrahim Malang). el-Qudwah .

Wilhelm Von Humboldt, C. J. 2015. Some Thoughts on Character Education for Today's University. Journal Of Character Education .
Winarni, S. 2013. Integrasi Pendidikan Karakter dalam Perkuliahan. Jurnal Pendidikan Karakter .

\section{UCAPAN TERIMA KASIH}

Terima kasih disampaikan kepada Fakultas Hukum yang telah memberikan kesempatan untuk melakukan penelitian DPP/SPP 2019 dan Pusat MPK Universitas

Brawiajaya yang memberikan fasilitas dalam mengikuti kegiatan ini sehingga naskah ini dapat terselesaikan dengan baik 